\title{
Silver and Silver Chloride Nanoparticles and their Anti-Tick Activity: a Mini Review
}

\author{
Nelson Durán,,$^{*, a, b, c}$ Marcela Durán ${ }^{*, b, d}$ and Celso E. de Souza ${ }^{e}$ \\ ${ }^{a}$ Laboratório de Química Biológica and ${ }^{b}$ NanoBioss, Instituto de Química, \\ Universidade Estadual de Campinas, 13083-970 Campinas-SP, Brazil \\ 'Laboratório Nacional de Nanotecnologia (LNNano-CNPEM), 13083-100 Campinas-SP, Brazil \\ ${ }^{d}$ Laboratório de Carcinogenese Urogenital e Imunoterapia, \\ Departamento de Genética, Evolução e Bioagentes, Instituto de Biologia, \\ Universidade Estadual de Campinas, 13083-970 Campinas-SP, Brazil \\ ${ }^{e}$ Laboratório de Parasitoses por Flagelados, Superintendência de Controle de Endemias (SUCEN), \\ 01027-000 São Paulo-SP, Brazil
}

\begin{abstract}
This overview highlights the importance of characterization of biogenic nanoparticles of silver and silver chloride in order to understand the action on ticks or pathogens transmitted by them. These nanoparticles appear as important active principles in this area. They can act against ticks or against major pathogens transmitted by the bite of ticks such as bacteria, viruses or protozoa with equal or better efficacy of antibiotics, antiviral or antiparasitic agents. Anti-tick activities on Rhipicephalus (Boophilus) microplus, Hyalomma anatolicum, Hyalomma isaaci and Haemaphysalis bispinosa are discussed. Perspectives of these nanoparticles acting on bacteria, viruses and protozoa infections are also discussed.
\end{abstract}

Keywords: ticks, silver nanoparticles, silver chloride nanoparticles, anti-tick agents

\section{Introduction}

Ticks are vectors of many infections as they are able to carry bacteria, virus and also protozoan agents. ${ }^{1}$ Related to the bacterial diseases transmitted by ticks are Lyme disease, rickettsioses, and tularemia. ${ }^{2-7}$

Tiboviruses (tick-borne viruses) cause many symptoms with severe effects that affect the central nervous system, such as meningitis, meningoencephalitis with high sequelae, and hemorrhagic diseases. ${ }^{8-10}$

Protozoan infections, for example, the babesiosis (Babesia bigemina), may also be transmitted by ticks. ${ }^{11-13}$ Toxin production can cause paralysis, from Dermacentor andersoni (Rocky Mountain wood tick), Dermacentor variabilis (dog ticks), and Ixodes holocyclus (marsupial ticks). ${ }^{14-16}$ In this last and rare case, the mainstay of treatment for tick's paralysis, tick removal, and the time to full neurological recovery after tick removal are generally estimated to be around 1.5 days with initial improvement within hours. ${ }^{17,18}$

*e-mail: duran@iqm.unicamp.br; marceladuranduran@ gmail.com
In Brazil, the main disease transmitted by ticks to humans is spotted fever (BSF) whose etiologic agent is Rickettsia rickettsii, which is an intracellular gram-negative bacterium. The main vector is Amblyomma sculptum and the disease is considered a major public health problem. ${ }^{19,20}$

The rise in the number of notified cases and the expansion of transmission area and elevated lethality rate have been observed in the country since 80 's. Lethality rate in the southeast region of Brazil ranges between 30 to $50 \%$, and in São Paulo and Minas Gerais states one can found the most notifications of this disease..$^{19,21}$

An excellent alternative for treatment of these diseases is the use of nanobiotechnology as a novel strategy in this area. One important nanostructure is the silver nanoparticles $\left(\mathrm{Ag}^{0}\right)$ or also nanoparticles of the silver cloride $(\mathrm{AgCl})$.

The silver nanoparticles biogenically synthesized are widely studied by many research groups in the world ${ }^{22-39}$ and $\mathrm{Ag}^{0}$ nanoparticles were quite efficient against Aedes aegypti. ${ }^{40}$

The biogenic silver nanoparticles effects on ticks were studied against ticks' larvae and adult ticks. ${ }^{41,42}$ 
It is important to be aware that the characterizations of these silver nanostructures are of paramount importance, since there are many reports in the literature in which erroneous characterization of silver structures were published. The X-ray diffraction (XRD) pattern for $\mathrm{Ag}^{0}$ as well as for $\mathrm{AgCl}$ nanoparticles, which are the most common silver nanostructures that are biogenically synthesized, were discussed recently by Seabra et al. ${ }^{43}$ Based on aforementioned discussion on XRD characterization of biogenic silver nanostructures, herein the anti-tick activities are to be discussed.

The XRD patterns for $\mathrm{Ag}^{0}$ nanoparticles (JCPDS file No. 04-0783 or ICSD Code 64994) and for $\mathrm{AgCl}$ nanoparticles (JCPDS file No. 85-1355 or ICSD Code 64734) were used to construct Table 1.

\section{Anti-Tick Activity}

Marimuthu et al ${ }^{42}$ biosynthesized silver nanoparticles from leaf extract of Mimosa pudica Gaertn. (Mimosaceae) and tested those nanoparticles against the larvae of Rhipicephalus (Boophilus) microplus Canestrini, 1887 (Acari: Ixodidae) (R. (B.) microplus). In this case the silver nanostructure was classified as $\mathrm{Ag}^{0}$ nanoparticles. Analyzing the XRD pattern data the nanostructure studied also exhibited values that correspond to $\mathrm{AgCl}$ nanoparticles (low presence) $\mathrm{Ag}^{0}$ and/or silver oxides as spherical morphology. Reported nanoparticles exhibited an efficacy of $\mathrm{LC}_{50}$ of $8.98 \mu \mathrm{g} \mathrm{mL}^{-1}$ against the larvae of $R$. (B.) microplus. At the concentration of 15 and $20 \mu \mathrm{g} \mathrm{mL}$, a 51 and $89 \%$ of mortality was found, respectively. The size of the nanoparticles by transmission electron microscopy (TEM) was around $25-60 \mathrm{~nm}$ and by scanning electron microscopy (SEM) were $25-50 \mathrm{~nm}$.

The synthesis of mainly $\mathrm{AgCl}$ nanoparticles and with presence of low $\mathrm{Ag}^{0}$ nanoparticles silver nanoparticles from leaf extract of Ocimum canum Sims (Labiatae) against the larvae of Hyalomma anatolicum (a.) anatolicum Koch, 1844 (actual name $H$. anatolicum) and Hyalomma marginatum (m.) isaaci Sharif, 1928 (Acari: Ixodidae) (actual name $H$. isaaci) was achieved. ${ }^{41}$ SEM analyses were crucial to determine the size of the synthesized $\mathrm{AgCl}$ nanoparticles that was estimated to be $25-110 \mathrm{~nm}$. The particles exhibited spherical and after drying formed rod and cubic morphology. These nanoparticles exhibited effect against $H$. anatolicum and H. isaaci with the $\mathrm{LC}_{50}$ values of 0.78 and $1.00 \mu \mathrm{g} \mathrm{mL}^{-1}$, respectively, and caused $100 \%$ mortality at $2.5 \mu \mathrm{g} \mathrm{mL}^{-1}$. Probably, in this case the cubic form of $\mathrm{AgCl}$ exerted a better activity than $\mathrm{AgCl}$ in its spherical morphology. ${ }^{47} \mathrm{It}$ is known that spherical and cubes as in the case of $\mathrm{AgCl}$ in this case, exhibits similar biological activities.

Stem aqueous extract of Cissus quadrangularis biosynthesis of $\mathrm{AgCl}$ nanoparticles and their effects

Table 1. Anti-tick activities of silver and silver chloride nanoparticles

\begin{tabular}{|c|c|c|c|c|c|c|}
\hline Biomaterial & $\begin{array}{l}\text { XRD pattern } \\
\text { designation }\end{array}$ & $\begin{array}{l}\text { Size / nm } \\
\text { Structure }\end{array}$ & Ticks & $\begin{array}{c}\mathrm{LD}_{50} / \\
(\mu \mathrm{g} \mathrm{mL}-1)\end{array}$ & $\begin{array}{l}\text { Concentration } \\
\text { (mortality) / } \\
\left(\mu \mathrm{g} \mathrm{mL} \mathrm{mL}^{-1}\right)(\%)\end{array}$ & Reference \\
\hline $\begin{array}{l}\text { Musa paradisiaca }(\mathrm{L} .) \\
\text { (Musaceae) (plant) }\end{array}$ & $\begin{array}{l}\mathrm{Ag}(\text { low } \mathrm{AgCl} \\
\text { presence) }\end{array}$ & $\begin{array}{l}\text { 50-150 }(\mathrm{SEM}) \\
\text { spherical }\end{array}$ & $\begin{array}{c}\text { larvae of Haemaphysalis bispinosa } \\
\text { Neumann (Acarina: Ixodidae) }\end{array}$ & 1.87 & $5.0(100)$ & 44 \\
\hline $\begin{array}{l}\text { Euphorbia prostrata } \\
\text { Ait (plant) }\end{array}$ & $\mathrm{Ag}$ & $\begin{array}{l}\text { 25-80 (SEM) } \\
\text { spherical }\end{array}$ & $\begin{array}{c}\text { adult cattle tick Haemaphysalis bispinosa } \\
\text { Neumann (Acarina: Ixodidae) }\end{array}$ & 2.30 & $10.0(100)$ & 45 \\
\hline $\begin{array}{l}\text { Manilkara zapota }(\mathrm{L} .) \\
\text { (plant) }\end{array}$ & $\mathrm{Ag}$ & $\begin{array}{l}70-140(\text { SEM }) \\
\text { spherical }\end{array}$ & $\begin{array}{c}\text { larvae Rhipicephalus (Boophilus) } \\
\text { microplus }\end{array}$ & 3.44 & $10.0(100)$ & 46 \\
\hline $\begin{array}{l}\text { Streptomyces sp. LK3 } \\
\text { (bacteria) }\end{array}$ & $\mathrm{AgCl}$ & $\begin{array}{c}\text { 5-20 }(\text { TEM }) \\
\text { spherical }\end{array}$ & $\begin{array}{c}\text { larvae Rhipicephalus microplus and } \\
\text { Haemaphysalis bispinosa }\end{array}$ & $\begin{array}{l}16.10 \\
16.45\end{array}$ & - & 47 \\
\hline $\begin{array}{l}\text { Ocimum canum Sims } \\
\text { (Labiatae) (plant) }\end{array}$ & $\begin{array}{l}\mathrm{AgCl} \text { (low } \mathrm{Ag} \\
\text { presence) }\end{array}$ & $\begin{array}{l}\text { 25-100 (SEM) } \\
\text { spherical and after } \\
\text { drying formed rod } \\
\text { and cubic structures }\end{array}$ & $\begin{array}{l}\text { larvae of Hyalomma anatolicum Koch, } \\
1844 \\
\text { Hyalomma isaaci (Acari: Ixodidae) }\end{array}$ & $\begin{array}{l}0.78 \\
1.00\end{array}$ & $\begin{array}{l}2.5(100) \\
2.5(100)\end{array}$ & 41 \\
\hline $\begin{array}{l}\text { Cissus quadrangularis } \\
\text { (plant) }\end{array}$ & $\begin{array}{c}\mathrm{AgCl} \text { (low } \mathrm{Ag} \\
\text { presence) }\end{array}$ & $\begin{array}{l}43(\text { SEM) } \\
\text { spherical }\end{array}$ & $\begin{array}{c}\text { larvae of Rhipicephalus (Boophilus) } \\
\text { microplus }\end{array}$ & 7.61 & $25.0(100)$ & 48 \\
\hline $\begin{array}{l}\text { Mimosa pudica } \\
\text { Gaertn (plant) }\end{array}$ & $\begin{array}{l}\mathrm{AgCl} \text { and } \mathrm{Ag} \\
\text { presence }\end{array}$ & $\begin{array}{c}25-50(\mathrm{SEM}) \\
\text { spherical }\end{array}$ & $\begin{array}{l}\text { larvae Rhipicephalus (Boophilus) } \\
\text { microplus Canestrini (Acari:Ixodidae) }\end{array}$ & 8.98 & $\begin{array}{l}15(51) \\
20(89)\end{array}$ & 42 \\
\hline $\begin{array}{l}\text { Carissa carandas } \\
\text { (plant) }\end{array}$ & $\begin{array}{l}\text { silver non } \\
\text { characterized }\end{array}$ & $\begin{array}{l}40-50(\text { TEM }) \\
\text { spherical }\end{array}$ & $\begin{array}{l}\text { adult cattle ticks Rhipicephalus } \\
\text { (Boophilus) microplus }\end{array}$ & - & $\begin{array}{l}5.0 \mathrm{mg} \mathrm{mL}^{-1}(40) \\
\text { low reproductive } \\
\text { index }\end{array}$ & 49 \\
\hline
\end{tabular}

SEM: Scanning electron microscopy; TEM: transmission electron microscopy. 
against the larvae of $R$. (B.) microplus were studied. ${ }^{48}$ The size of the nanoparticles as determined by FESEM was $43 \mathrm{~nm}$. The activity against the larvae of $R$. (B.) microplus exhibited $\mathrm{LC}_{50}$ values of 7.61 and at $25 \mu \mathrm{g} \mathrm{mL}^{-1}$ and $100 \%$ of mortality for adult $R$. (B.) microplus was also observed. This nanostructure exhibited lower activity than any $\mathrm{Ag}^{0}$, since this nanoparticle is spherical as in Marimuthu et al. ${ }^{42}$

Aqueous leaf extract from Musa paradisiaca (L.) (Musaceae) led to the synthesis of silver nanoparticles (mainly) and some $\mathrm{AgCl}$ nanoparticles were also present and their application against the larvae of Haemaphysalis bispinosa Neumann (Acarina: Ixodidae) (H. bispinosa) was reported. ${ }^{44}$ By SEM the size was 20-30 $\mathrm{nm}$ and exhibiting the $\mathrm{LC}_{50}$ of $1.87 \mu \mathrm{g} \mathrm{mL}^{-1}$ and at concentration of $5 \mu \mathrm{g} \mathrm{mL}^{-1}$, those nanoparticles provoked $100 \%$ of mortality. The spherical morphology in $\mathrm{Ag}^{0}$ exerted an important biological activity.

Aqueous leaf extract from Euphorbia prostrata Ait. was used for the synthesis $\mathrm{Ag}^{0}$ nanoparticles (mainly with traces of $\mathrm{AgCl}$ nanoparticles) and studied against the adult cattle tick $H$. bispinosa. ${ }^{45}$ SEM analysis showed a size of $25-80 \mathrm{~nm}$. The $\mathrm{LC}_{50}$ value observed was $2.3 \mu \mathrm{g} \mathrm{mL} \mathrm{m}^{-1}$ and

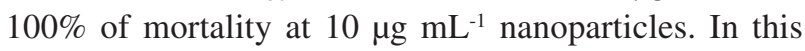
preparation the $\mathrm{Ag}^{0}$ presented a spherical morphology and similar activities than in the work of Marimuthu et $a l .^{42}$

Rajakumar and Rahuman ${ }^{46}$ synthesized from aqueous extract of Manilkara zapota (L.) mainly $\mathrm{Ag}^{0}$ nanoparticles (spherical morphology) and traces of $\mathrm{AgCl}$ nanoparticles as seen by XRD pattern. A size of 70-140 nm by SEM was determined. $\mathrm{LC}_{50}$ values against $R$. (B.) microplus was $3.44 \mu \mathrm{g} \mathrm{mL}^{-1}$ and at a concentration of $10 \mu \mathrm{g} \mathrm{mL}^{-1}$ exhibited a $100 \%$ mortality.

The synthesis of $\mathrm{AgCl}$ nanoparticles from Streptomyces sp. LK3 showed acaricidal activity against $R$. (B.) microplus and $H$. bispinosa with $\mathrm{LC}_{50}$ values of 16.10 and $16.45 \mu \mathrm{g} \mathrm{mL}^{-1}$, respectively. ${ }^{47}$ In this case, the exhibited plasmon absorption can be associated to a very low $\mathrm{Ag}^{0}$ nanoparticles concentration present. The presence of $\mathrm{AgCl}$ in its spherical form exerts a low activity as compared with $\mathrm{Ag}^{0}$.

Evaluation of acaricidal efficacy (against $R$. (B.) microplus) of plant mediated synthesis of silver nanoparticles using Carissa carandas leaf extract (40-50 nm by TEM) was reported. Adult immersion test was used to evaluate the efficacy of silver nanoparticles against cattle ticks. Results showed $40 \%$ mortality with silver nanoparticles (non characterized by XRD diffractions pattern and probably $\mathrm{AgCl}$ ) using a high concentration ( $5 \mathrm{mg} \mathrm{mL}^{-1}, 72 \mathrm{~h}$ ). The effect was further observed on the reproductive indices of ticks which exhibited significant decrease in this index with increasing concentrations of silver nanoparticles. ${ }^{49}$
Larvae and adult $H$. bispinosa were affected in the same extension $\left(\mathrm{LD}_{50}\right.$ ca. $\left.2 \mu \mathrm{g} \mathrm{mL}^{-1}\right)$ and similar mortality percentage from $\mathrm{Ag}^{0}$ nanoparticles from different sources (Musa paeadisiaca) ${ }^{44}$ and Euphorbia prostate. ${ }^{45}$ However, $\mathrm{AgCl}$ nanoparticles from Streptomyces ${ }^{47}$ showed to be 8 -fold less effective than ones obtained from the plant sources.

Larvae $R$. (B.) microplus was affected by $\mathrm{Ag}^{0}$ nanoparticles differently when different sources of the $\mathrm{Ag}^{0}$ nanoparticles were used. The $\mathrm{LD}_{50}$ from Manilkara zapota $\left(3.44 \mu \mathrm{g} \mathrm{mL}^{-1}\right)^{46}$ and from Mimosa pudica $\left(8.98 \mu \mathrm{g} \mathrm{mL}^{-1}\right)^{42}$ were found. At the same extension mortality were 3-fold more efficient in Manilkara than in Mimosa. In the presence of $\mathrm{AgCl}$ nanoparticles, the same value of $\operatorname{LD}_{50}(7.61 \mu \mathrm{g} \mathrm{mL}-1)$ was obtained by the source of Cissus quadrangularis with a similar mortality ${ }^{48}$ against the ticks. $\mathrm{AgCl}$ nanoparticles produced by Streptomyces exhibited a lower effect against the tested ticks $\left(\mathrm{LD}_{50}\right.$ ca.16 $\left.\mu \mathrm{g} \mathrm{mL}^{-1}\right)$ (Table 1$)$.

Larvae of $H$. anatolicum and $H$. marginatum were affected significantly by $\mathrm{AgCl}$ nanoparticles synthesized by Ocimum canum Sims with $\mathrm{LD}_{50}$ of 0.78 and $1.0 \mu \mathrm{g} \mathrm{mL} \mathrm{m}^{-1}$, respectively. ${ }^{41}$ Probably, in this case the spherical form that after drying formed rod and cubic structures exerted a high biological activity in a similar or better profile than $\mathrm{Ag}^{0}$.

It is known that silver triangular nanoplates have basic $\{111\}$ surface, nanospheres and nanocubes mainly have $\{100\}$ planes, and nanorods have $\{100\}$ side surfaces and $\{111\}$ end facets. Then, the data said that $\{111\}$ crystal plane of silver nanoparticles may play a prime role in antibacterial progress. Recently was reported that silver triangle nanoplates had the best antibacterial activity, while nanospheres, nanocubes and short nanorods showed similar efficacy. ${ }^{50}$

This was reinforced with MIC values of $\mathrm{Ag}^{0}$ nanoparticles $(60 \mathrm{~nm})$ in which the cubic form and spherical one were 37.5 and $75 \mu \mathrm{g} \mathrm{mL}{ }^{-1}$, respectively. ${ }^{51}$ The fact is, the particles covered by $\{100\}$ facets (cubic form) showed stronger antibacterial activity than those covered by $\{111\}$ facets (spherical). This was demonstrated on Table 1.

The Table 1 shows a summary of all the anti-tick activities of biogenic silver nanoparticles. Fortunately, with the discrimination of the XRD pattern, it was possible to get some conclusions.

In conclusion, $\mathrm{Ag}^{0}$ and $\mathrm{AgCl}$ nanoparticles are efficient anti-tick agents, however, their activities depend on the source of production of nanoparticles and from their morphologies. Due to this factor, $\mathrm{AgCl}$ in its spherical morphology exhibited less activity than spherical $\mathrm{Ag}^{0}$.

Another factor that has to be considered when evaluating effects of the cited nanoparticles are the effects of the capped proteins from the biogenic nanoparticles, 
which probably due to the specificity of the protein corona interaction may strongly affect nanoparticles' activities. ${ }^{26}$

\section{Tick-Borne Diseases}

\subsection{Bacteria}

Bacteria genera most common in the ticks' infection are Borrelia (a genus of Gram-negative, aerobic, spirochete bacteria), Francisella (a genus Gram-negative, aerobic, coccobacillary or rod shaped, nonmotile bacteria), Coxiella (a genus of Gram-negative, aerobic, rod-shaped or spore-like particles, acidophilic bacteria), Rickettsia (a genus of non motile, Gram-negative, aerobic, obligate intracellular parasites, non spore-forming, highly pleomorphic bacteria that can present as cocci) and Ehrlichia (a genus of Gram-negative, aerobic, obligate intracellular parasites, rickettsia-shaped bacteria).

Burgdorfer, ${ }^{52}$ who is well known researcher in Lyme diseases, tested in vitro proteinate silver (colloidal silver or Argyrol) up to $1500 \mathrm{ppm}\left(1.5 \mathrm{mg} \mathrm{mL}^{-1}\right)$ on bacteria that cause Lyme disease (Borrelia burgdorferi spirochetes). ${ }^{53,54}$ These bacteria disappeared in less than five minutes and twenty-four hours later, none of the crops treated contained any living spirochetes. Similar results were observed with another bacterium, such as Borrelia hermsii (HS-1), the agent of relapsing fever.

As far as we know, no other bacteria in this area were studied under influence of silver nanoparticles. However, it is known from the literature, ${ }^{23,35-38,55}$ that Gram-negative bacteria are effectively eliminated by $\mathrm{Ag}^{0}$ nanoparticles. Then, the antibacterial studies regarding tick-borne infections are an open area for research.

\subsection{Virus}

The most known viruses from tick infections are the tickborne viruses of the families Asfarviridae, Rhabdoviridae and Orthomyxoviridae, Reoviridae, Bunyaviridae and Flaviviridae, genus Flavivirus (around 200 viruses). ${ }^{8}$

$\operatorname{Argovit}\left(12 \mathrm{mg} \mathrm{mL}^{-1}\right)$ that is spherical silver nanoparticles of $35 \pm 15 \mathrm{~nm}$ functionalized with poly(vinylpyrrolidone) (PVP, 10-30 kD) were tested on Rift Valley fever virus (RVFV) in a Vero cell cultures and on mice lacking the type I interferon receptor (IFNAR [-/-] mouse infection model). In cells infected with RVFV a viral reduction of $50 \%$ of the total virus was found. But, pre-incubation of RVFV with silver nanoparticles at concentrations of $0.2 \mathrm{mg} \mathrm{mL}^{-1}$, abolished almost completely viral propagation, leading to $98 \%$ reduction of infectivity. Daily administration of silver nanoparticles by oral gavages to lethally infected mice, previously incubated with $20 \mathrm{mg} \mathrm{mL}^{-1}$ of silver nanoparticles showed a delayedonset clinical disease and mortality, with a survival rate of $60 \%$. The authors suggested that these results revealed the potential application of the microbiocide properties of silver nanoparticles to control the infectivity of this important zoonotic pathogen. ${ }^{56}$

In addition to the antimicrobial activity against bacteria of silver nanoparticles, there is strong evidence that they are also active against several viruses, including human immunodeficiency virus, hepatitis B virus, herpes simplex virus, respiratory syncytial virus and monkey pox virus. These metal nanostructures generate an important opportunity for the development of new antiviral therapies with a large number of targets, reducing viral resistance that can commonly happen with conventional antivirals. ${ }^{57}$

\subsection{Protozoan}

Protozoan infection babesiosis (Babesia bigemina) is transmitted by ticks ${ }^{13}$ and, in a similar way, leptospirosis by Ixodes ricinus ${ }^{58}$ and leishmaniasis by Rhipicephalus sanguineus. ${ }^{59}$

The effectiveness of silver nanoparticles as an alternative therapy for leishmaniasis, specifically by subcutaneous intralesional administration for cutaneous leishmaniasis was demonstrated ${ }^{60}$ Biogenic silver nanoparticles (mainly $\mathrm{Ag}^{0}$ nanoparticles) against Leishmania amazonensis promastigotes showed to be 4-fold more effective than silver nanoparticles chemically synthesized. In vivo studies in infected mice demonstrated that the biogenic silver nanoparticles were equally effective as 300 -fold higher doses of amphotericin B, and more effective than 4-fold higher doses of chemically synthesized one. ${ }^{61}$

The possibility of using silver nanoparticles on protozoan infections was summarized by Rai et al.$^{62}$ These facts demonstrated that we need more research in order to eliminate these types of contamination provoked by ticks.

\section{Perspectives and Final Remarks}

It is important to mention that it was clear from these analyzed data that reliable nanoparticles characterization and morphology are important in the biological activities. Then, the data said that $\{111\}$ crystal plane of silver nanoparticles may play a prime role in antibacterial progress.

Another important conclusion is also that either $\mathrm{Ag}^{0}$ or $\mathrm{AgCl}$ nanoparticles or both together were effective against ticks or the propagation of the tick-borne infections. All 
data indicated that the antibacterial and antiviral studies regarding tick-borne infections are an open area for research.

Then, we hope that this overview might incentive the researchers to study ticks-producer diseases more thoroughly in order to eradicate this problem globally.

\section{Acknowledgments}

Supports from FAPESP, CNPq, INOMAT (MCTI/ CNPq), NanoBioss (MCTI) and Brazilian Network on Nanotoxicology (MCTI/CNPq) are acknowledged.

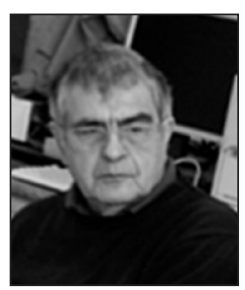

Nelson Durán is a Professor of Chemistry at the Universidade Estadual de Campinas (UNICAMP, Brazil). He received his $P h D$ at University of Porto Rico (USA) working on photolysis and thermolysis of 1,2-dioxolanes (1972). Associated Professor at the Universidad Catolica de Valparaiso, Chile (1973-1975) and carried out Visiting Professorship at Universidade de São Paulo, Brazil (1975), investigating enzymatic generation of excited states intermediates. In 1978, he joined the Chemistry Institute of UNICAMP (Brazil) working in Biological Chemistry and Biotechnology. His present research interests are nanobiotechnology in cosmetics and in pharmaceuticals, besides metallic nanoparticles as antibiotics and anticancer carriers, and in carbon and silica nanocarriers. He is the Coordinator of the Brazilian Nanotoxicology Network; member of INOMAT (MCTI/ $C N P Q)$ and Vice Coordinator of NanoBioss (MCTI) and member of Brazilian-NanoReg (European Community) in vivo nanotoxicology.

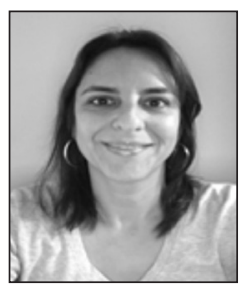

Marcela Durán is a pharmacist, Researcher Associated in Carcinogenesis Laboratory Urogenital and Immunotherapy Anatomy, at Biology Institute of the Universidade Estadual de Campinas (UNICAMP). She is graduated at Universidade São Francisco (USF), São Paulo, Brazil. Currently she is developing research project related to Nanotechnology area, such as cell regeneration and stem cells. She has a Master in Food Technology (UNICAMP, 2004) and PhD in Medical Sciences (UNICAMP, 2014). She is member of Brazilian-NanoReg Toxicology group (European Community) working in in vivo study of carbon nanotubes by instillation on rats associated to NanoBioss (MCTI).

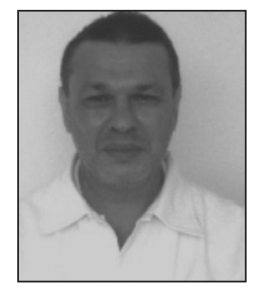

Celso Eduardo de Souza is a Veterinarian of the Superintendence Control of Endemic Diseases of the Government of the State of São Paulo, Brazil. He graduated in Veterinary Medicine from the Universidade de Alfenas (1984-1988). Master in Animal Health area of concentration in Epidemiology by Universidade Federal Rural do Rio de Janeiro (2010). He holds a doctorate degree in Collective Health from the Faculty of Medical Sciences of the Universidade Estadual de Campinas (UNICAMP, 2015). He has experience in Preventive Veterinary Medicine, working mainly in research and diagnosis in the following subjects: Zoonosis and Public Health, epidemiology, parasitology and vectorborne diseases with emphasis on diseases transmitted by ticks. Technical advisor of the Program of Epidemiological Surveillance of Brazilian Spotted Fever and other Riquettoses of the Ministry of Health of Brazil.

\section{References}

1. Kon, K.; Rai, M. In Nanotechnology in Diagnosis, Treatment and Prophylaxis of Infections Diseases; Rai, M.; Kon, K., eds.; Elsevier: London, UK, 2015, ch. 3, p. 39.

2. Parola, P.; Raoult, D.; Clin. Infect. Dis. 2001, 32, 89.

3. Parola, P.; Paddock, C. D.; Raoult, D.; Clin. Microbiol. Rev. 2005, 18, 719.

4. Foley, J. E.; Nieto, N. C.; Vet. Microbiol. 2010, 140, 332.

5. Kung, F.; Anguita, J.; Pal, U.; Future Microbiol. 2013, 8, 41.

6. Portillo, A.; Santibañez, S.; García-Alvarez, L.; Palomar, A. M.; Oteo, J. A.; Microbes Infect. 2015, 17, 834.

7. Borchers, A. T.; Keen, C. L.; Huntley, A. C.; Gershwin, M. E.; J. Autoimmun. 2015, 57, 82.

8. Labuda, M.; Nuttall, P. A.; Parasitology 2004, 129, S221.

9. Hubálek, Z.; Rudolf, I.; Parasitol. Res. 2012, 111, 9.

10. Pujalte, G. G. A.; Chua, J. V.; Prim. Care 2013, 40, 619.

11. Amsden, J. R.; Warmack, S.; Gubbins, P. O.; Pharmacotherapy 2005, 25, 191.

12. Schnittger, L.; Rodriguez, A. E.; Florin-Christensen, M.; Morrison, D. A.; Infect., Genet. Evol. 2012, 12, 1788.

13. Barto, D.; Brzozowski, J.; Nurs. Crit. Care 2014, 9, 23.

14. Diaz, J. H.; J. Med. Toxicol. 2010, 6, 15.

15. Diaz, J. H.; Clin. Toxicol. 2015, 53, 874.

16. Teong, J. M. Y.; Adler, P. A.; Doggett, S. L.; Danehvar, D.; Shields, M. K.; Case Rep. Ophthalmol. 2015, 6, 120.

17. Pecina, C. A.; Semin. Neurol. 2012, 32, 531.

18. Taraschenko, O. D.; Powers, K. M.; Pediatr. Neurol. 2014, 50, 605.

19. Lima, V. L. C.; Souza, S. S. L.; Souza, C. E.; Vilela, M. F. G.; Papaiordanou, P. M. O.; Del Guércio, V. M. F.; Cad. Saúde Pública (CSP) 2003, 19, 331. 
20. Katz, G.; Camargo-Neves, V. L. F.; Angerami, R. N.; Nascimento, E. M. M.; Colombo, S.; Bol. Epidemiol. Paul. (BEPA) 2009, 6, 4.

21. Nasser, J. T.; Lana, R. C.; Silva, C. M.; Lourenço, R. W.; da Cunha e Silva, D. C.; Donalicio, M R.; Rev. Bras. Epidemiol. 2015, 18, 299.

22. Durán, N.; Marcato, P. D.; Teixeira, Z.; Durán, M.; Costa, F. T. M.; Brocchi, M.; Curr. Nanosci. 2009, 5, 396.

23. Durán, N.; Marcato, P. D.; de Conti, R.; Alves, O. L.; Costa, F. T. M.; Brocchi, M.; J. Braz. Chem. Soc. 2010, 21, 949.

24. Durán, N.; Marcato, P. D.; Durán, M.; Yadav, A.; Gade, A.; Rai, M.; Appl. Microbiol. Biotechnol. 2011, 90, 1609.

25. Durán, N.; Seabra, A. B.; de Lima, R. In Nanotoxicology: Materials, Methodologies, and Assessments; Durán, N.; Guterres, S. S.; Alves, O. L., eds.; Springer: New York, 2014, ch. 11, p. 245.

26. Durán, N.; Silveira, C. P.; Durán, M.; Martinez, D. S. T.; J. Nanotechnol. 2015, 13, 55.

27. Durán, M.; Silveira, C. P.; Durán, N.; IET Nanobiotechnol. 2015, 9, 314.

28. Rai, M.; Yadav, A.; Gade, A.; Biotechnol. Adv. 2009, 27, 76.

29. Marcato, P. D.; Durán, M.; Huber, S.; Rai, M.; Melo, P. S.; Alves, O. L.; Durán, N.; J. Nano Res. 2012, 20, 99.

30. Ingal, A. G.; Chaudhari, A. N.; J. Nanomed. Nanotechol. 2013, $4,2$.

31. Abbasi, E.; Milani, M.; Aval, S. F.; Kouhi, M.; Akbarzadeh, A.; Nasrabadi, H. T.; Nikasa, P.; Joo, S. W.; Hanifehpour, Y.; NejatiKoshki, K.; Samiei, M.; Crit. Rev. Microbiol. 2008, 42, 173.

32. Faramarzi, M. A.; Sadighi, A.; Adv. Colloid Interface Sci. 2013, 189-190, 1.

33. Gowramma, B.; Keerthi, U.; Rafi, M.; Rao, D. M.; 3 Biotech 2015, 5, 195.

34. Mittal, J.; Batra, A.; Singh, A.; Sharma, M. M.; Adv. Nat. Sci.: Nanosci. Nanotechnol. 2014, 5, 043002.

35. Mashwani, Z.; Khan, T.; Khan, M. A.; Nadhman, A.; Appl. Microbiol. Biotechnol. 2015, 99, 9923.

36. Natsuki, J.; Natsuki, T.; Hashimoto, Y.; Int. J. Mater. Sci. Appl. 2015, 4, 325.

37. Moghaddam, A. B.; Namvar, F.; Moniri, M.; Tahir, P.; Azizi, S.; Mohamad, R.; Molecules 2015, 20, 16540.

38. Keat, C. L.; Aziz, A.; Eid, A. M.; Elmarzugi, N. A.; Bioresour. Bioprocess. 2015, 2, 47.

39. Picoli, S. U.; Durán, M.; Andrade, P. F.; Durán, N.; Front. Nanosci. Nanotechnol. 2016, 2, 107.

40. Durán, N.; Islan, G. A.; Durán, M.; Castro, G. R.; J. Braz. Chem. Soc. 2016, 27, 1139.

41. Jayaseelan, C.; Rahuman, A. A.; Parasitol. Res. 2012, 111, 1369.

42. Marimuthu, S.; Rahuman, A. A.; Rajakumar, G.; Santhoshkumar, T.; Kirthi, A. V.; Jayaseelan, C.; Bagavan, A.; Zahir, A. A.; Elango, G.; Kamaraj, C.; Parasitol. Res. 2011, 108, 1541.
43. Seabra, A. B.; Nakazato, G.; Durán, N.; Appl. Microbiol. Biotechnol. 2016, 100, 6555 .

44. Jayaseelan, C.; Rahuman, A. A.; Rajakumar, G.; Santhoshkumar, T.; Kirthi, A. V.; Marimuthu, S.; Bagavan, A.; Kamaraj, C.; Zahir, A. A. S.; Elango, G.; Velayutham, K.; Rao, K. V. B.; Karthik, L.; Raveendran, S.; Parasitol. Res. 2012, 111, 921.

45. Zahir, A. A., Rahuman, A. A.; Vet. Parasitol. 2012, 187, 511.

46. Rajakumar, G.; Rahuman, A. A.; Res. Vet. Sci. 2012, 93, 303.

47. Karthik, L.; Kumar, G.; Kirthi, A. V.; Rahuman, A. A.; Rao, K. V. B.; Bioprocess Biosyst. Eng. 2014, 37, 261.

48. Santhoshkumar, T.; Rahuman, A. A.; Bagavan, A.; Marimuthu, S.; Jayaseelan, C.; Kirthi, A. V.; Kamaraj, C.; Rajakumar, G.; Zahir, A. A.; Elango, G.; Velayutham, K.; Iyappan, M.; Siva, C.; Karthik, L.; Rao, K. V. B.; Exp. Parasitol. 2012, 132, 156.

49. Johari, P.; http://shodhganga.inflibnet.ac.in/handle/10603/2363, accessed in November 2016.

50. Hu, G.; Jin, W.; Chen, Q.; Cai, Y.; Zhu, Q.; Zhang, W.; Appl. Phys. A 2016, 122, 874.

51. Hong, X.; Wen, J.; Xiong, X.; Hu, Y.; Environ. Sci. Pollut. Res. 2016, 23, 4489.

52. Burgdorfer, W.; Rev. Infect. Dis. 1986, 8, 932.

53. Burgdorfer, W.; From Penicillin to Mild Silver Protein - An Answer to Lyme Disease Without Antibiotics; Rocky Mountain Laboratories, National Institute of Health (Agency of the U.S. Department of Health), USA, 1995.

54. Schwan, T. G.; Burgdorfer, W.; Department of Health and Human Services, National Institutes of Health, Rocky Mountain Laboratories, January 13, 1995. Available at http://www.xpressnet. com/bhealthy/bhealthy.html, accessed in February 2017.

55. Lemire, J. A.; Harrison, J. J.; Turner, R. J.; Nature Rev. Microbiol. 2013, 11, 371.

56. Borrego, B.; Lorenzo, G.; Mota-Moralez, J. D.; Almanza-Reyez, H.; Mateos, F.; López-Gil, E.; de la Losa, N.; Burmistrov, V. A.; Pestryakov, A.; Brun, A.; Bogdanchikova, N.; Nanomedicine 2016, 12, 1185 .

57. Galdiero, S.; Falanga, A.; Vitiello, M.; Cantisani, M.; Marra, V.; Galdiero, M.; Molecules 2011, 16, 8894.

58. Wójcik-Fatla, A.; Zajac, V.; Cisak, E.; Sroka, J.; Sawczyn, A.; Dutkiewicz, J.; Ann. Agric. Environ. Med. 2012, 4, 656.

59. Campos, J. H. F.; Costa, F. A. L.; Rev. Inst. Med. Trop. São Paulo 2014, 56, 297.

60. Islan, G. A.; Durán, M.; Cacicedo, M. L.; Nakazato, G.; Kobayashi, R. K. T.; Martinez, D. S. T.; Castro, G. R.; Durán, N.; Acta Trop. 2017, 170, 16.

61. Rossi-Bergmann, B.; Pacienza-Lima, W.; Marcato, P. D.; de Conti, R.; Durán, N.; J. Nano Res. 2012, 20, 89.

62. Rai, M.; Kon, K. Ingle, A.; Durán, N.; Galdiero, S.; Galdiero, M.; Appl. Microbiol. Biotechnol. 2014, 98, 1951.

Submitted: December 16, 2016

Published online: March 9, 2017 